\title{
PEMBERDAYAAN MASYARAKAT MELALUI KEGIATAN KERAJINAN TANGAN ECENG GONDOK 'IYAN HANDICRAFT' (STUDI DI DUSUN KENTENG, GADINGSARI, SANDEN, BANTUL, YOGYAKARTA)
}

\section{COMMUNITY EMPOWERMENT THROUGH TO WATER HYACINTH HANDICRAFT ACTIVITIES 'IYAN HANDICRAFT' (STUDY IN KENTENG VILLAGE, GADINGSARI, SANDEN, BANTUL, YOGYAKARTA)}

\author{
Oleh: Suswarina Andri Aswari, Universitas Negeri Yogyakarta \\ rinaaswari18@gmail.com
}

\begin{abstract}
Abstrak
Tujuan penelitian ini untuk mendeskripsikan: 1) proses pemberdayaan masyarakat melalui kegiatan kerajinan tangan eceng gondok 'Iyan Handicraft', 2) faktor pendukung dan penghambat dalam pemberdayaan masyarakat melalui kegiatan kerajinan tangan eceng gondok 'Iyan Handicraft', 3) dampak dalam pemberdayaan masyarakat melalui kegiatan kerajinan tangan eceng gondok 'Iyan Handicraft'.

Penelitian ini merupakan penelitian deskriptif dengan menggunakan pendekatan kualitatif. Subyek penelitian adalah 2 pengelola, 11 tenaga kerja, dan 2 keluarga tenaga kerja 'Iyan Handicraft'. Pengumpulan data menggunakan wawancara, observasi, dan dokumentasi. Teknik analisis data yang digunakan adalah reduksi data, penyajian data, dan penarikan kesimpulan. Teknik keabsahan data menggunakan triangulasi metode

Hasil penelitian menunjukkan bahwa: 1) proses pemberdayaan masyarakat melalui a) tahap penyadaran, b) tahap penguatan potensi atau daya, c) tahap pelaksanaan tindakan nyata, dan d) tahap evaluasi. 2) faktor pendukung yaitu (a) bahan baku eceng gondok mudah didapat dan murah, (b) mudah dalam pemasaran poduk, (c) proses pembuatan kerajinan eceng gondok mudah, (d) tersedianya fasilitas yang memadai, (e) adanya motivasi dan minat yang tinggi dari tenaga kerja, (f) adanya waktu luang dan dukungan dari keluarga tenaga kerja. Faktor penghambat yaitu (a) kurangnya tenaga kerja, (b) perubahan cuaca yang mempengaruhi penjemuran eceng gondok. 3) dampak yaitu (a) dari segi ekonomi yaitu pendapatan tenaga kerja semakin meningkat, (b) dari segi sosial yaitu membuka lapangan pekerjaan, mengurangi pengangguran dan hubungan sosial terjalin baik, (c) dari segi lingkungan yaitu mengurangi dampak negatif dari tanaman eceng gondok di daerah perairan, dan (d) dari segi pendidikan yaitu tenaga kerja mempunyai pengetahuan dan keterampilan dalam membuat kerajinan tangan eceng gondok.
\end{abstract}

Kata Kunci: pemberdayaan masyarakat, kerajinan tangan, eceng gondok

\section{Abstract}

The study aims to describe: 1) the process of community empowerment through to water hyacinth handicraft activities 'Iyan Handicraft', 2) supporting and inhibiting factors of the community empowerment through to water hyacinth handicraft activities 'Iyan Handicraft', 3) the impact of the community empowerment through to water hyacinth handicraft activities 'Iyan Handicraft'.

The research is a descriptive research with qualitative approach. The subjects of this research are 2 the manager of Iyan Handicraft, 11 the labors and 2 family of labors of Iyan Handicraft. The data were collected using observation, interview and documentation. Data analysis techniques used are data reduction, data display and conclusion. The technique of data validity using triangulation method.

The result show that: 1) the process of community empowerment is: a) the awareness phase, b) the strengthening of potential or power phase, c) the implementation of the real act phase, d) the evaluation phase. 2) the supporting factor is: (a) raw materials water hyacinth is posible and cheap, (b) easy in its marketing, (c) the process of making hyacinth handicraft is easy, (d) the availability of facilities and infrastructure must be provided, (e) the high motivation and interest from the workforce, (f) the free times and supports of the family labor. The inhibiting factor is: (a) lack of manpower, (b) weather changes that affect drying water hyacinth. 3) the impact is (a) from economic aspect is income labor increasing, (b) from social aspect is open job opportunities, reduce unemployment, and social relations been long established, (c) from environment aspect is reducing the negative impact of a plant water hyacinth in the areas of waters, and (d) from education aspect is worker has knowledge and skill in making handicrafts water hyacinth. 


\section{Diklus: Jurnal Pendidikan Luar Sekolah, 1(2), September 2017 - 195 Suswarina Andri Aswari}

Keywords: Community empowerment, handicraft, water hyacinth.

\section{PENDAHULUAN}

Pembangunan merupakan suatu upaya yang dilakukan dalam rangka menunjang kesejahteraan masyarakat. Pembangunan sebagai sarana transformasi atau perubahan ekonomi, sosial dan budaya yang di gerakkan atas tujuan untuk meningkatan kualitas hidup manusia.

Proses pembangunan tidak akan terlepas dari campur tangan manusia sebagai sumber daya pelaksana pembangunan. Pentingnya peran manusia untuk memajukan pembangunan bangsa perlu didukung dengan adanya sumber daya manusia yang berkualitas. Sumber daya manusia yang berkualitas adalah manusia yang memiliki perilaku yang baik dalam penguasaan ilmu dan teknologi, sikap, moral, budi pekerti dan keterampilan serta handal dalam melaksanakan pembangunan daerah (Moh. Shofan, 2007: 104).

Data World Population Data Sheet 2016, menunjukkan penduduk Indonesia sejumlah 259.4 juta jiwa. (www.prb.org). Tingginya jumlah penduduk di Indonesia dapat menimbulkan permasalahan serius bagi pembangunan bangsa ditambah dengan tidak didukungnya sumber daya manusia yang kualitas. Berdasarkan laporan data UNDP dalam HDR (Human Development Report) 2016, kualitas sumber daya manusia Indonesia masih tergolong rendah dibanding negara lainnya khususnya negara di ASEAN. IPM (Indeks Pembangunan Manusia) Indonesia berada pada peringkat 113 dari 188 negara di dunia dengan nilai indeks 0.689. Sedangkan negara Singapura di peringkat 5, Brunei Darussalam peringkat 30, Malaysia peringkat 59, dan Thailand peringkat 87. (hdr.undp.org/sites/default/files/2016_human_deve lopment_report.pdf).

Rendahnya sumber daya manusia di Indonesia berakibat pada timbulnya masalah kemiskinan dan meningkatnya penganngguran.. Permasalahan kemiskinan seringkali terkait dengan ketidakberdayaan dan kerentanan masyarakat dalam memenuhi kebutuhan hidup. Orang miskin biasanya tidak memiliki daya atau kemampuan yang cukup di banyak bidang, karena tidak memiliki keterampilan yang mendukung untuk meningkatkan pendapatan sehingga dapat berdampak pada peningkatan pengangguran.

Kemiskinan dan pengangguran sangat identik di wilayah pedesaan. Masyarakat di pedesaan yang memiliki pola pikir statis, tradisional dan sulit menerima inovasi, pada akhirnya desa tidak akan mampu berkembang dan akan menjadi desa tertinggal dan terbelakang. Masalah yang ada di pedesaan perlu segera diatasi agar kualitas hidup masyarakat desa dapat meningkat. Salah satu solusinya dengan melaksanakan pembangunan masyarakat desa.

Pembangunan masyarakat adalah suatu upaya terencana dan sistematis yang dilakukan oleh, untuk, dan dalam masyarakat guna meningkatkan kualitas hidup penduduk dalam semua aspek kehidupannya di dalam suatu kesatuan wilayah (Sudjana, 2001:261). Pembangunan masyarakat desa akan efektif apabila melibatkan masyarakat sebagai subjek pembangunan. Dimana masyarakat terlibat secara langsung dalam proses perencanaan, pelaksanaan dan evaluasi di berbagai kegiatan pembangunan. Masyarakat diberi kuasa penuh untuk memilih 


\section{Diklus: Jurnal Pendidikan Luar Sekolah, 1(2), September 2017 - 196 Suswarina Andri Aswari}

sendiri jenis dan keragaman kegiatan yang sesuai dengan potensi dan kebutuhan masyarakat dalam usaha memecahkan masalah di kehidupan mereka.

Pendidikan Luar Sekolah merupakan sarana yang tepat karena Pendidikan Luar Sekolah berbasis pada pendidikan sepanjang hayat dan berkelanjutan. Pendidikan Luar Sekolah juga menggarap program-program pendidikan yang berorientasi pada pembangunan masyarakat. Melalui program-program pendidikan luar sekolah, masyarakat desa dibekali dengan pengetahuan, keterampilan dan sikap mental yang positif. Dengan demikian masyarakat desa dapat lebih mandiri dan berdaya dalam meningkatkan kualitas hidupnya.

Program pemberdayaan masyarakat merupakan salah satu cakupan program pendidikan luar sekolah yang dapat memberikan kontribusi besar dalam upaya pembangunan masyarakat. Kegiatan pemberdayaan masyarakat dilaksanakan dengan fokus untuk membuat masyarakat mandiri dalam usaha memberdayakan lingkungan dan potensi-potensi yang dimiliki masyarakat agar tercapai kualitas hidup yang baik.

Kegiatan kerajinan tangan menjadi salah satu program kegiatan yang memiliki kontribusi yang besar bagi pemberdayaan masyarakat desa. Kegiatan kerajinan tangan memiliki prospek yang cerah karena produk kerajinan memiliki peran penting dalam mendukung pertumbuhan ekonomi di Indonesia.

Adanya program kegiatan kerajinan tangan merupakan salah satu solusi untuk mengurangi pengangguran di pedesaan, meningkatkan pendapatan masyarakat, meningkatkan kualitas sumber daya manusia, serta mampu menciptakan lapangan pekerjaan baru dengan mengoptimalkan potensi yang ada di lingkungan pedesaan.

Kerajinan tangan bisa dibuat dengan memanfaatkan barang-barang yang berlebihan atau bahan-bahan yang dianggap tidak berguna untuk dioah menjadi barang-barang yang multi fungsi dan bernilai ekonomis. Eceng gondok termasuk salah satu tanaman yang dapat dimanfaatkan sebagai bahan pembuatan kerajinan tangan.

Tanaman eceng gondok termasuk tanaman gulma (pengganggu) karena memiliki pertumbuhan yang cepat dan dapat merusak tanaman yang ada di sekitarnya. Tanaman eceng gondok juga berdampak negatif bagi wilayah perairan seperti menimbulkan pencemaran air. Limbah tanaman eceng gondok yang mati akan mengalami pembusukan (dekomposisi) sehingga akan berakibat pula pada pendangkalan di wilayah perairan.

Salah satu cara untuk mengurangi dampak negatif dari tanaman eceng gondok di wilayah perairan adalah dengan memanfaatkan dan mengolah tanaman eceng gondok menjadi produk kerajinan tangan. Di Desa Gadingsari, Sanden, Bantul terdapat salah satu dusun bernama Dusun Kenteng yang bergerak dalam pembuatan kerajinan tangan dari bahan baku tangkai eceng gondok.

Kegiatan pembuatan kerajinan tangan eceng gondok di Dusun Kenteng tersebut diberi nama 'Iyan Handicraft'. Kegiatan pembuatan kerajinan tangan eceng gondok 'Iyan Handicraft' dilaksanakan untuk memanfaatkan tanaman eceng gondok yang masih melimpah. Selain itu dilaksanakannya kegiatan kerajinan tangan eceng 


\section{Diklus: Jurnal Pendidikan Luar Sekolah, 1(2), September 2017 - 197 \\ Suswarina Andri Aswari}

gondok 'Iyan Handicraft' sebagai bentuk keprihatinan pengelola 'Iyan Handicraft' terhadap kondisi perekonomian di Dusun Kenteng yang masih rendah karena 83\% masyarakat Dusun Kenteng bermata pencaharian di sektor agraris dengan menjadi petani. Pendapatan yang diperoleh dari bekerja sebagai petani tidak cukup untuk memenuhi kebutuhan hidup keluarga yang semakin bertambah. Tingkat pendidikan masyarakat di Dusun Kenteng masih rendah, hampir 80\% masyarakat Dusun Kenteng hanya lulusan SD, SMP dan SMA. Di Dusun Kenteng masih ditemui sejumlah $65 \%$ masyarakat yang belum mampu atau miskin.

Program pemberdayaan masyarakat melalui kegiatan pembuatan kerajinan tangan eceng gondok 'Iyan Handicraft' di Dusun Kenteng dimaksudkan untuk memfasilitasi masyarakat yang memiliki keterampilan menganyam serta membantu memberdayakan masyarakat, terutama masyarakat miskin agar lebih sejahtera. Proses pelaksanaan program kegiatan pembuatan kerajinan tangan eceng gondok 'Iyan Handicraft' dalam usaha memberdayakan masyarakat di Dusun Kenteng mendorong peneliti untuk melakukan penelitian mengenai "Pemberdayaan Masyarakat Melalui Kegiatan Kerajinan Tangan Eceng Gondok 'Iyan Handicraft' (Studi di Dusun Kenteng, Gadingsari, Sanden, Bantul, Yogyakarta)”.

\section{METODE PENELITIAN}

\section{Jenis Penelitian}

Pendekatan penelitian yang digunakan dalam penelitian ini adalah pendekatan kualitatif. Menurut Lexy Moleong (2007: 6), penelitian kualitatif adalah penelitian yang bermaksud untuk memahami fenomena tentang apa yang dialami oleh subyek penelitian pada suatu konteks khusus yang alamiah dan dengan memanfaatkan berbagai metode ilmiah. Oleh karena itu permasalahan yang dibahas dalam penelitian ini akan menghasilkan data berupa kata-kata baik data secara lisan maupun tertulis dan berupa gambar yang bertujuan untuk mendeskripsikan, menguraikan, dan menggambarkan data hasil penelitian melalui katakata.

\section{Subjek Penelitian}

Subyek penelitian dalam penelitian ini yaitu 2 pengelola Iyan Handicraft. Selain itu juga informan pendukung yaitu 8 tenaga kerja tetap dan 3 tenaga kerja pengrajin anyam eceng gondok yang mengikuti kegiatan kerajinan tangan eceng gondok "Iyan Handicraft" dan 2 keluarga dari tenaga kerja yang mengikuti kegiatan kerajinan tangan eceng gondok "Iyan Handicraft".

\section{Setting Penelitian}

Setting penelitian dilakukan di Iyan Handicraft yang berlokasi di Dusun Kenteng, Gadingsari, Sanden, Bantul, Yogyakarta. Waktu yang akan digunakan oleh peneliti untuk melakukan penelitian ini yaitu dari bulan Mei sampai bulan Agustus 2017. Alasan peneliti memilih Iyan Handicraft sebagai tempat penelitian yaitu Iyan Handicraft sebagai salah satu dusun yang mengembangkan kegiatan kerajinan tangan dari bahan eceng gondok sebagai upaya pemberdayaan masyarakat yang saat ini telah berkembang dengn cukup pesat, lokasi atau letak Iyan Handicraft mudah dijangkau peneliti sehingga memudahkan peneliti dalam melaksanakan 


\section{Diklus: Jurnal Pendidikan Luar Sekolah, 1(2), September 2017 - 198 \\ Suswarina Andri Aswari}

penelitian dan adanya sisi keterbukaan dari pihak pengelola maupun tenaga kerja Iyan Handicraft.

\section{Teknik Pengumpulan Data}

Menurut Lexy Moleong (2007: 225) dalam penelitian kualitatif, pengumpulan data dilakukan pada natural setting (kondisi yang alamiah), sumber data primer, dan teknik pengumpulan data lebih banyak pada observasi, wawancara dan dokumentasi. Begitu pula data-data dalam penelitian ini berupa informasi-informasi yang didapat dari subjek penelitian dengan menggunakan teknik pengumpulan data berupa observasi, wawancara, dan dokumentasi.

\section{Teknik Analisis Data}

Menurut Bogdan \& Biklen dalam Moleong (2007: 248) analisis data kualitatif adalah upaya yang dilakukan dengan jalan bekerja dengan data, mengorganisasikan data, memilah-milahnya menjadi satuan yang dapat dikelola, mensintesiskannya, mencari dan menemukan pola, menemukan apa yang penting dan apa yang dipelajari, dan memutuskan apa yang dapat diceriterakan kepada orang lain.

Analisis bertujuan menyederhanakan olahan hasil data kualitatif yang disusun secara terinci, sistematis dan terus menerus melalui langkah langkah:

\section{Reduksi Data}

Menurut Sugiyono (2007: 247) reduksi data adalah merangkum, memilih hal-hal pokok, memfokuskan pada hal-hal yang penting, dicari tema dan polanya. Data yang telah direduksi akan memberikan gambaran yang lebih jelas, dan mempermudah peneliti untuk melakukan pengumpulan data selanjutnya.
2. Penyajian Data

Setelah melakukan reduksi data, langkah selanjutnya yaitu mendisplaikan data atau penyajian data. Dalam penelitian kualitatif, penyajian data bisa dilakukan dalam bentuk uraian singkat, bagan, hubungan antar kategori, flowchart, dan sejenisnya. Dengan mendisplaykan data ini, akan memudahkan untuk memahami apa yang terjadi, merencanakan kerja selanjutnya berdasarkan apa yang telah dipahami tersebut

\section{Penarikan Kesimpulan}

Kesimpulan data dalam penelitian kualitatif ini kemungkinan dapat menjawab rumusan masalah yang dirumuskan sejak awal, namun mungkin juga tidak. Hal itu disebabkan karena masalah dan rumusan masalah dalam penelitian kualitatif masih bersifat sementara dan akan berkembang setelah penelitian berada di lapangan.

\section{Keabsahan Data}

Menurut Moleong (2007: 330) trianggulasi adalah teknik pemeriksaan keabsahan data yang memanfaatkan sesuatu yang lain. Di luar data itu digunakan untuk keperluan pengecekan atau sebagai pembanding terhadap data itu. Untuk memperoleh data yang semakin dipercaya maka data yang diperoleh dari wawancara juga dilakukan pengecekan melalui pengamatan, atau melakukan wawancara tentang hal yang serupa kepada sumber lainnya

Dalam penelitian ini, peneliti menggunakan trianggulasi metode, dilakukan dengan cara cara mengecek data kepada sumber yang sama dengan teknik yang berbeda. Dengan demikian tujuan dari 


\section{Diklus: Jurnal Pendidikan Luar Sekolah, 1(2), September 2017 - 199}

Suswarina Andri Aswari

trianggulasi adalah untuk membandingkan informasi tentang hal yang sama sehingga ada jaminan kepercayaan dan menghindari subjektivitas dari peneliti.

\section{HASIL PENELITIAN DAN PEMBAHASAN}

\section{A. Hasil Penelitian}

\section{Proses pemberdayaan Masyarakat}

a. Tahap penyadaran

Tahap awal pemberdayaan masyarakat melalui kegiatan kerajinan tangan eceng gondok Iyan Handicraft adalah tahap penyadaran. Penyadaran dilakukan dengan cara kegiatan penyuluhan yang dilakukan pengelola yang bekerja sama dengan beberapa kepala dusun di Kecamatan Sanden. Selanjutnya penyadaran juga dilakukan dengan komunikasi dialogis antara pengelola dengan calon tenaga kerja.

b. Tahap penguatan potensi atau daya

Tahap penguatan potensi atau daya masyarakat dilaksanakan dengan kegiatan pelatihan. Kegiatan pelatihan dilakukan oleh pengelola dengan cara pemberian materi dan praktek langsung di tempat baik di tempat penyuluhan di rumah kepala dusun masing-masing dan di tempat produksi Iyan Handicraft.

c. Tahap pelaksanaan tindakan nyata

1) Proses produksi

Tempat dilaksanakannya kegiatan pemberdayaan masyarakat melalui kerajinan tangan eceng gondok berada di tempat produksi Iyan Handicraft untuk kegiatan pembuatan cetakan kerangka anyaman eceng gondok dan kegiatan finishing. Sedangkan untuk kegiatan menganyam eceng gondok dilaksanakan di rumah masing-masing pengrajin anyaman.

Alokasi waktu untuk tenaga kerja tetap sudah terjadwal dengan baik yaitu pada hari Senin sampai Sabtu pukul 08.00 - 16.00 WIB. Sedangkan untuk pengrajin anyam, tidak ada alokasi waktu khusus karena dikerjakan di rumah masing-masing dan disesuaikan dengan waktu senggang pengrajin anyam.

Proses kegiatan produksi kerajinan tangan eceng gondok terlaksana jika ada pesanan dari konsumen. Pelaksanaan kegiatan pembuatan kerajinan eceng gondok dilakukan dengan melibatkan masyarakat sekitar dan sebagian besar dikerjakan secara borongan oleh para ibu disekitar tempat produksi.

Pelaksanaan kegiatan dilakukan dengan adanya pembagian tugas disesuaikan dengan kemampuan dan keinginan tenaga kerja serta disesuaikan dengan kegiatan yang sedang dibutuhkan dalam proses produksi. Pembagian tugas dilakukan dengan tiga tahapan yaitu: tahap awal, dibagian pembuatan cetakan untuk 
Diklus: Jurnal Pendidikan Luar Sekolah, 1(2), September 2017 - 200

Suswarina Andri Aswari

kerangka eceng gondok dan proses penjemuran eceng gondok, tahap penganyaman dibagian pembuatan anyaman eceng gondok yang dilakukan oleh pengrajin eceng gondok, dan tahap finishing.

Suasana yang terbentuk selama pelaksanaan kegiatan kerajinan eceng gondok dibuat senang dengan diselingi canda tawa agar tidak bosan dalam pelaksanaan proses produksi. Sehingga tenaga kerja bisa enjoy, senang dan mampu menambah semangat kerja dalam melaksanakan kegiatan pembuatan kerajinan tangan eceng gondok.

Proses interaksi atau hubungan tenaga kerja dengan pengelola terjalin baik, yaitu dengan saling bertukar pendapat mengenai kegiatan kerajinan eceng gondok ini. Selama kegiatan berlangsung, pengelola selalu mendampingi jalannya kegiatan dan pengelola tidak segan-segan untuk ikut bekerja bersama tenaga kerja, dan tenaga kerja juga sering bertanya kepada pengelola kalau ada yang kurang diketahui, dan pengelola selalu menanggapinya dengan ramah

Proses interaksi antartenaga kerja.juga berjalan baik yaitu tenaga kerja maupun pengrajin bisa saling kerja sama dan saling bantu jika ada yang mengalami kesulitan. Tenaga kerja juga saling bertukar pendapat dan saling tanya jika ada yang tidak diketahui.

2) Pendampingan

Pendampingan merupakan salah satu tahapan yang dilakukan dalam proses pemberdayaan masyarakat. Di Iyan Handicraft pendampingan dilaksanakan oleh pengelola dan ketua sub masing-masing kelompok pengrajin anyam eceng gondok. Pendampingan oleh pengelola dilakukan dari proses awal sampai proses akhir dalam pembuatan kerajinan tangan eceng gondok. Sedangkan pendampingan oleh ketua sub di masing-masing kelompok pengrajin anyam eceng gondok dilakukan saat proses penganyaman saja.

d. Tahap Evaluasi

Tahap evaluasi dalam proses kegiatan kerajinan tangan eceng gondok Iyan Handicraft dilakukan oleh pengelola dengan memantau langsung proses produksi pembuatan kerajinan eceng gondok dari awal sampai akhir

\section{Faktor pendukung dan penghambat} pemberdayaan masyarakat

a. Faktor pendukung

Faktor pendukung dalam proses pemberdayaan masyarakat melalui kegiatan kerajinan eceng gondok Iyan Handicraft yaitu 1) bahan baku eceng gondok yang mudah di dapat dan murah, 2) mudahnya pemasaran poduk 


\section{Diklus: Jurnal Pendidikan Luar Sekolah, 1(2), September 2017 - 201}

Suswarina Andri Aswari

kerajinan eceng gondok, 3) proses pembuatan kerajinan eceng gondok mudah, 4) tersedianya sarana dan prasarana yang memadai di Iyan Handicraft, 5) adanya motivasi dan minat yang tinggi dari tenaga kerja untuk melaksanakan kegiatan kerajinan eceng gondok, 6) adanya waktu luang dari tenaga kerja dan dukungan dari keluarga tenaga kerja.

b. Faktor penghambat

Faktor penghambat dalam proses pembuatan kerajinan tangan eceng gondok Iyan Handicraf yaitu sebagai berikut: 1) kurangnya tenaga kerja, 2) perubahan cuaca yang tidak menentu mengakibatkan eceng cepat menjamur jika tidak keringmerata.

\section{Dampak pemberdayaan masyarakat}

a. Segi ekonomi, pendapatan tenaga kerja semakin meningkat.

b. Segi sosial, membuka lapangan pekerjaan, memberikan kesempatan kerja bagi masyarakat yang membutuhkan pekerjaan dan mengurangi pengangguran di daerah pedesaan. Selain itu semakin mempererat tali persaudaraan antarsesama manusia.

c. Segi lingkungan, membantu pemerintah dalam mengurangi dampak negatif dari adanya tanaman eceng gondok di perairan Indonesia. d. Segi pendidikan, pengetahuan, keterampilan dan sikap masyarakat semakin meningkat terutama mengenai bidang kerajinan khususnya kerajinan tangan dari eceng gondok.

\section{B. Pembahasan}

Kegiatan kerajinan tangan eceng gondok Iyan Handicraft merupakan salah satu bentuk kegiatan pemberdayaan masyarakat karena proses pelaksanaan kegiatan produksi kerajinan tangan eceng gondok dilaksanakan secara bertahap dan berkesinambungan.

\section{Proses pemberdayaan masyarakat}

a. Tahap penyadaran

Tahap penyadaran dilakukan melalui kegiatan penyuluhan dan kegiatan komunikasi dialogis. Kegiatan penyuluhan dilakukan oleh pengelola Iyan Handicraft yang datang ke beberapa dusun di Kecamatan Sanden. Pengelola Iyan Handicraft dibantu oleh Kepala Dusun masing-masing untuk mengumpulkan warga masyarakat setempat guna mengikuti penyuluhan tentang kegiatan kerajinan tangan eceng gondok 'Iyan Handicraft'.

Selama kegiatan penyuluhan pengelola Iyan Handicraft berusaha menciptakan prakondisi atau suasana iklim yang memungkinkan potensi masyarakat berkembang, salah satunya dengan menggambarkan kesuksesan suatu program kegiatan kerajinan tangan eceng gondok yang pernah 
Diklus: Jurnal Pendidikan Luar Sekolah, 1(2), September 2017 - 202

Suswarina Andri Aswari

dilaksanakan di daerah lain,

menggambarkan kesuksesan pengrajin menyampaikan informasi tentang kerajinan tangan eceng gondok dan mengajak masyarakat agar turut berpartisipasi dalam mengembangkan industri rumah tangga khususnya industri kerajinan dari bahan eceng gondok. Pada tahap penyadaran ini sangat sesuai dengan teori dari Kartasasmita dalam Zubaedi (2014: 79) tentang upaya pemberdayaan masyarakat yang dinyatakan pada poin pertama yaitu menciptakan suasana iklim yang memungkinkan potensi masyarakat berkembang (enabling).

Sedangkan tahap penyadaran untuk tenaga kerja yang diajak langsung oleh pengelola maupun dari rekomendasi tenaga kerja lama atau pelamar kerja yang datang langsung ke Iyan Handicraft untuk bergabung di Iyan Handicraft dengan melakukan komunikasi dialogis.

Bentuk komunikasi dialogis yang dilakukan oleh pengelola terhadap calon tenaga kerja baru Iyan Handicraft dengan saling membangun kepercayaan satu sama lain dengan cara menciptakan kondisi yang santai, nyaman saat mengenalkan dan menginformasikan kegiatan kerajinan tangan eceng gondok 'Iyan Handicraft'.

Melalui kegiatan komunikasi dialogis ini pengelola juga eceng gondok yang ada di daerah lain, yang diharapkan mampu membuka harapan-harapan baru bagi calon tenaga kerja untuk meningkatkan kualitas hidup.

Komunikasi dialogis yang dilaksanakan pengelola Iyan Handicraft sesuai dengan pendapat Freire dalam (Oos M Anwas, 2014: 103) menyatakan bahwa:

"penyadaran sebagai suatu proses yang berkesinambungan dimana orang bergerak menuju kesadaran kritisnya dengan melalui metode pedagogi dialogis, pedagogi problematis, dan pedagogi politik. Pedagogi dialogis sebagai proses pendidikan dilakukan secara dialogis untuk membahas dan mencari solusi tentang berbagai hal guna meningkatkan kesejahteraan hidup manusia. Dalam dialog ini, terkandung empati antara lain dua kutub yang berkomunikasi, rendah hati, penuh harapan, kepercayaan, dan sikap kritis.

b. Tahap penguatan potensi atau daya

Tahap penyadaran masyarakat perlu didukung dengan adanya penguatan dan peningkatan potensi diri. Penguatan dan peningkatan potensi diri di Iyan Handicraft dilakukan malalui kegiatan pelatihan. Hal tersebut sesuai teori dari Kartasasmita dalam Zubaedi (2014: 79) yang menyatakan bahwa memperkuat potensi atau daya yang dimiliki masyarakat (empowering) dapat diupayakan melalui berbagai aktivitas nyata seperti pendidikan, peningkatan kesehatan, pelatihan, pemberian modal, 


\section{Diklus: Jurnal Pendidikan Luar Sekolah, 1(2), September 2017 - 203}

Suswarina Andri Aswari

informasi, lapangan pekerjaan, pasar dan sarana prasarana lainnya untuk memperkuat potensi dan daya masyarakat.

Kegiatan pelatihan sebagai salah satu sarana yang sangat penting dalam proses pemberdayaan masyarakat karena sebagai upaya meningkatkan kemampuan masyarakat menuju peningkatan kualitas hidupnya.

Kegiatan pelatihan di Iyan Handicraft dilaksanakan dengan metode praktek secara langsung di tempat. Materi praktek yang diberikan selama proses penyuluhan yaitu menganyam eceng gondok kering.

Sedangkan kegiatan pelatihan di tempat produksi Iyan Handicraft dilaksanakan dengan metode coaching. Dimana pengelola Iyan Handicraft mengajarkan dan membimbing tenaga kerja baru dengan praktek langsung tentang langkah-langkah memproduksi anyaman eceng gondok baik dari proses awal yaitu penjemuran bahan baku eceng gondok sampai proses akhir yaitu finishing produk kerajinan eceng gondok.

c. Tahap pelaksanaan tindakan nyata

Proses pemberdayaan masyarakat setelah kegiatan pelatihan yaitu pelaksanaan tindakan nyata. Pelaksanaan tindakan nyata dilakukan dengan cara menghadapkan masyarakat secara langsung dalam proses kegiatan kerajinan tangan eceng gondok 'Iyan Handicraft'.

Pelaksanaan proses produksi di Iyan Handicraft dilakukan jika ada pesanan dari konsumen. Pesanan berasal dari trading yang akan mengeksport barang kerajinan ke luar negeri dan dari perusahaan atau toko-toko kerajinan di DIY yang nantinya akan dijual kembali ke konsumen.

Pelaksanaan proses produksi dilakukan dengan adanya penempatan atau pembagian tugas dimasing-masing bidang sesuai kemampuan dan kemauan dari tenaga kerja serta disesuaikan dengan kegiatan yang sedang dibutuhkan dalam proses produksi. Penempatan dan pembagian tugas bertujuan untuk membangun tanggungjawab tenaga kerja agar pekerjaan dapat dilakukan dengan adil, merata dan tidak menimbulkan persaingan antartenaga kerja sehingga akan lebih terbangun solidaritas kelompok.

Kartasasmita dalam Zubaedi (2014: 79) pada poin ketiga menyatakan bahwa upaya pemberdayaan masyarakat dilakukan dengan melindungi masyarakat (protecting) dari persaingan yang tidak seimbang, sehingga perlu adanya aturan atau kesepakatan yang jelas dan tegas dan jelas untuk melindungi golongan yang lemah.

Teori tersebut sesuai dengan pelaksanaan proses pemberdayaan 


\section{Diklus: Jurnal Pendidikan Luar Sekolah, 1(2), September 2017 - 204}

Suswarina Andri Aswari

masyarakat melalui kegiatan kerajinan tangan eceng gondok 'Iyan Handicraft' yang melakukan penempatan dan pembagian kerja dalam pelaksanaan proses pemberdayaan masyarakat melalui kegiatan kerajinan tangan eceng gondok 'Iyan Handicraft. Penempatan dan pembagian tugas sudah menjadi kesepaktan bersama antara pengelola dan tenaga kerja, sehingga pekerjaan dapat dilakukan dengan adil, merata dan tidak menimbulkan persaingan antartenaga kerja serta akan lebih terbangun solidaritas kelompok.

Kegiatan pendampingan dalam proses pemberdayaan masyarakat melalui kegiatan kerajinan tangan eceng gondok, dilakukan oleh pengelola Iyan Handicraft dan ketua sub kelompok pengrajin anyam eceng gondok.

Bentuk pendampingan yang dilakukan pengelola Iyan Handicraft adalah dengan ikut langsung dalam proses kegiatan dan melakukan proses memantau, memberikan arahan, mengajarkan dan melatih tenaga kerja dalam proses pembuatan kerajinan tangan eceng gondok baik dari proses awal sampai akjhir. Selain itu, pengelola Iyan Handicraft juga berperan sebagai komunikator yang akan menghubungkan antara konsumen atau pihak pemesan atau mitra kerja dengan tenaga kerja atau ketua sub kelompok pengrajin anyam dan sebaliknya.

Pendampingan yang dilakukan ketua sub kelompok pengrajin anyam eceng gondok adalah mengarahkan dan membantu pengrajin apabila mengalami kesulitan dalam proses penganyaman, selain itu juga turut berperan dalam menghubungkan antara pengelola Iyan Handicraft dengan pengrajin dan sebaliknya apabila ada kendala yang perlu diselesaikan secara bersama-sama.

Tugas dan peran pengelola Iyan Handicraft sebagai agen pemberdayaan masyarakat dalam kegiatan pendampingan program pemberdayaan masyarakat melalui kegiatan kerajinan tangan 'Iyan Handicraft; sudah sesuai dengan yang dikemukakan Zubaedi (2013: 64) yaitu:

1) Sebagai motivator, dilakukan oleh pendamping dengan menggali potensi sumber daya manusia, alam, dan mengembangkan kesadaran anggota masyarakat tentang kendala maupun permasalahan yang sedang dihadapi.

2) Sebagai komunikator, pendamping harus menerima mau menerima dan memberi informasi dari berbagai sumber kepada masyarakat untuk dijadikan rumusan dalam penanganan dan pelaksanaan berbagai program serta alternatif pemecahan masalahnya.

3) Sebagai fasilitator, pendamping memberi pengarahan tentang penggunaan 


\section{Diklus: Jurnal Pendidikan Luar Sekolah, 1(2), September 2017 - 205}

Suswarina Andri Aswari

berbagai strategi, teknik dan pendekatan dalam pelaksanaan program.

d. Tahap evaluasi

Evaluasi dalam proses kegiatan kerajinan tangan eceng gondok Iyan Handicraft dilakukan oleh pengelola dengan memantau langsung proses produksi pembuatan kerajinan eceng gondok dari awal sampai akhir.

Pemantauan dilakukan untuk: 1) mengetahui ada tidaknya perkembangan dari tenaga kerja selama pelaksanaan kegiatan kerajinan eceng gondok, 2) ada tidaknya kesesuaian produk yang dihasilkan dengan yang direncanakan dari awal, 3) kegiatan produksinya mengalami kemajuan atau kemunduran, dan 4) pencapaian apa saja yang sudah diraih dan perlu diraih.

Proses pemberdayaan yang dilakukan oleh 'Iyan Handicraft' sesuai dengan yang dikemukakan oleh Aziz dalam Alfitri (2011: 26) yaitu (1) tahap menemukan masalah, (2) tahap analisis masalah, (3) tahap penentuan skala prioritas masalah, (4) tahap mencari penyelesaian masalah, (5) tahap pelaksanaan tindakan nyata untuk menyelesaikan masalah, dan (6) tahap evaluasi.

Namun pada hasil penelitian dengan pendapat yang dikemukakan Aziz terdapat perbedaan dalam tahap awalnya. Pada penelitian ini tahap awal merupakan tahap penyadaran dan tahap penguatan potensi atau daya. Sedangkan dalam proses permberdayaan yang sesuai dengan pendapat Aziz adalah pada tahap pelaksanaan tindakan nyata untuk menyelesaikan masalah dan tahap evaluasi.

\section{Faktor pendukung dan penghambat}

a. Faktor pendukung

1) Bahan baku eceng gondok yang mudah di dapat dan murah.

Tanaman eceng gondok mampu hidup di daerah iklim tropis sampai subtropis. Sehingga Indonesia sebagai salah satu negara beriklim tropis tidak sulit untuk menemukan tanaman eceng gondok, baik di sungai, rawa, maupun danau.

2) Mudahnya pemasaran produk kerajinan eceng gondok.

Pemasaran produk yang mudah karena masih banyaknya peminat terhadap produk dari bahan alami seperti eceng gondok khususnya dari pangsa luar negeri.

3) Proses pembuatan kerajinan eceng gondok mudah,

Proses pembuatan kerajinan eceng gondok yang mudah karena hampir semua orang pasti pernah diajarkan caranya menganyam waktu SD, sedangkan untuk proses finishing merupakan kegiatan yang sering dilakukan dikehidupan sehari-hari masyarakat baik itu pencucian, pemotongan, penjemuran dan menyemprot yang bisa dikerjakan secara perorangan maupun kelompok.

4) Tersedianya sarana dan prasarana yang memadai di Iyan Handicraft. 
Diklus: Jurnal Pendidikan Luar Sekolah, 1(2), September 2017 - 206

Suswarina Andri Aswari

Sarana prasarana sangat

Tenaga kerja merupakan salah satu menentukan jalannya proses kegiatan. Iyan Handicraft memiliki sarana yang memadai baik dari segi alat, bangunan, dan transportasi semua mendukung jalannya proses produksi dari tahap awal yaitu penjemuran dan pembuatan cetakan kerangka sampai tahap akhir yaitu finishing semua tersedia.

5) Adanya motivasi dan minat yang tinggi dari tenaga kerja

Tenaga kerja Iyan Handicraft memiliki motivasi dan minat yang tinggi untuk melaksanakan kegiatan kerajinan eceng gondok. Hal tersebut terlihat dari tingkat kehadiran tenaga kerja ke Iyan Handicraft.

6) Adanya waktu luang dari tenaga kerja.

Tenaga kerja yang mayoritas sebagai petani dan buruh tani memiliki waktu luang yang banyak, karena pengerjaan di sawah hanya dilakukan waktu panen dan tandur. Sedangkan bagi pengrajin yang mayoritas ibu-ibu yang bermata pencaharian sebagai ibu rumah tangga, memiliki waktu luang yang banyak karena tidak ada pekerjaan lain yang dilakukan selain mengurus rumah. Sehingga dapat melakukan proses penganyamandi rumah masingmasing.

b. Faktor penghambat

1) Kurangnya tenaga kerja. bagian terpenting dalam berjalannya suatu kegiatan. Dimana tenaga kerja berfungsi sebagai motor penggerak suatu kegiatan, jika tidak adanya tenaga kerja atau kurangnya tenaga kerja maka akan mengakibatkan kegiatan produksi tersendat. Terlebih saat masa panen datang, tenaga kerja lebih memilih ke sawah daripada ke Iyan Handicraft karena hasilnya lebih besar.

2) Perubahan cuaca yang tidak menentu.

Cuaca sangat mempengaruhi proses produksi kerajinan tangan eceng gondok Iyan Handicraft. Saat musim hujan, eceng gondok lama mengering. Eceng gondok yang tidak kering merata dapat mengakibatkan eceng gondok menjadi keras dan sulit untuk dianyam. Eceng gondok yang tidak kering merata juga menyebabkan eceng gondok cepat menjamur sehingga produksi pembuatan kerajinan eceng gondok ikut terbengkalai.

\section{Dampak}

a. Segi ekonomi

Penghasilan dan pendapatan tenaga kerja semakin meningkat, dapat memenuhi kebutuhan primer maupun sekunder, dan mampu meningkatkan status ekonomi masyarakat di pedesaan.

b. Segi sosial, membuka lapangan pekerjaan, memberikan kesempatan kerja bagi masyarakat yang 


\section{Diklus: Jurnal Pendidikan Luar Sekolah, 1(2), September 2017 - 207 \\ Suswarina Andri Aswari}

membutuhkan pekerjaan dan mampu mengurangi pengangguran di daerah pedesaan. Selain itu semakin mempererat tali persaudaraan antarsesama manusia.

c. Segi lingkungan, membantu pemerintah dalam mengurangi dampak negatif dari adanya tanaman eceng gondok di perairan Indonesia.

d. Segi pendidikan, pengetahuan, sikap dan keterampilan masyarakat meningkat dan bertambah mengenai bidang kerajinan khususnya kerajinan tangan dari eceng gondok.

\section{KESIMPULAN DAN SARAN}

\section{Kesimpulan}

1. Proses pemberdayaan masyarakat melalui kegiatan kerajinan tangan eceng gondok Iyan Handicraft terjadi melalui empat tahapan yaitu: a) tahap penyadaran, b) tahap penguatan potensi atau daya, c) tahap pelaksanaan tindakan nyata, dan d) tahap evaluasi.

2. Faktor pendukung dan penghambat dalam pemberdayaan masyarakat melalui kegiatan kerajinan tangan eceng gondok Iyan Handicraft

a. Faktor pendukung yaitu (a) bahan baku eceng gondok mudah di dapat dan murah, (b) mudahnya pemasaran poduk, (c) proses pembuatan kerajinan eceng gondok mudah, (d) tersedianya sarana dan prasarana yang memadai, (e) adanya motivasi dan minat yang tinggi dari tenaga kerja, (f) adanya waktu luang dan dukungan keluarga dari tenaga kerja.

b. Faktor penghambat yaitu: (a) kurangnya tenaga kerja, (b) perubahan cuaca yang mempengaruhi penjemuran eceng gondok sehingga eceng gondok akan cepat menjamur dan keras jika belum kering merata

3. Dampak dari adanya pemberdayaan masyarakat melalui kegiatan kerajinan tangan eceng gondok Iyan Handicraft adalah: a) dari segi ekonomi yaitu pendapatan semakin meningkat, b) dari segi sosial yaitu membuka lapangan pekerjaan, mengurangi pengangguran dan hubungan sosial terjalin baik, c) dari segi lingkungan yaitu mengurangi dampak negatif dari tanaman eceng gondok di daerah perairan, dan d) tenaga kerja mempunyai pengetahuan dan keterampilan membuat kerajinan tangan eceng gondok.

\section{Saran}

1. Pengelola harus lebih aktif mensosialisasikan program kegiatan kerajinan eceng gondok Iyan Handicraft agar masyarakat mengetahui dan berminat untuk bergabung dengan program kegiatan kerajinan eceng gondok Iyan Handicraft sehingga dapat menambah sumber daya manusia.

2. Pengelola perlu mengatasi kendala cuaca dalam proses penjemuran dan pengeringan tangkai eceng gondok sehingga tidak menghambat proses produksi. 
3. Pengelola harus terus menjalin interaksi dan komunikasi yang baik dengan tenaga kerja, baik itu tenaga kerja tetap maupun tenaga kerja pengrajin anyam sistem borong, dengan ketua sub kelompok pengrajin eceng gondok dan mitra kerja.

4. Pengelola dan tenaga kerja harus terus menjaga kualitas produk dan ketepatan waktu sesuai target yang ditentukan jika bisa lebih ditingkatkan agar mendapat kepercayaan penuh dari mitra kerja.

\section{DAFTAR PUSTAKA}

Alfitri. (2011). Community Development. Yogyakarta: Pustaka Pelajar

Anwas, Oos M. (2014). Pemberdayaan Masyarakat di Era Global. Bandung: ALFABETA.

Human Development Report 2016 Team. (2016). Human Development Report 2016: Human Development for Everyone. Diakses dari hdr.undp.org/sites/default/files/2016_huma n_development_report.pdf. pada tanggal 23 April 2017, Jam 20.00 WIB

Moeleong, Lexy J. (2000). Metodologi Penelitian Kualitatif. Bandung: PT. Remaja Rosda Karya

Shofan, Moh. (Ed). (2007). The Realistic Education: Menuju Masyarakat Utama. Yogyakarta: IRCiSod.

Sudjana. (2001). Pendidikan Luar Sekolah: Wawasan, Sejarah, Perkembangan, Falsafah \& Teori Pendukung, serta Asas. Bandung: Falah Production.

Sugiyono. (2013). Metode Penelitian Pendidikan. Bandung: Alfabeta
World Population Data Sheet. (2016). Kependudukan. Diakses dari http://www.prb.org. pada tanggal 27 April 2017, Jam 20.30 WIB

Zubaedi. (2014). Pengembangan Masyarakat: Wacana dan Praktik. Jakarta: Kencana. 
Diklus: Jurnal Pendidikan Luar Sekolah, 1(2), September 2017 - 209

Suswarina Andri Aswari 